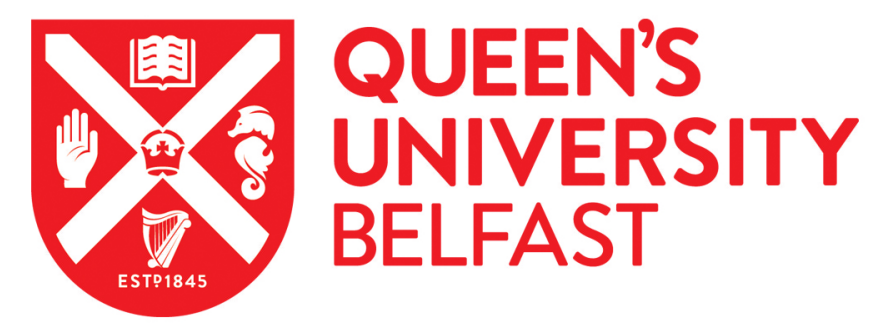

\title{
Mental health and well-being of parents caring for a ventilator- dependent child
}

Lee, J., \& Lynn, F. (2017). Mental health and well-being of parents caring for a ventilator-dependent child. Nursing Children \& Young People, 29(5), 33-40. https://doi.org/10.7748/ncyp.2017.e844

Published in:

Nursing Children \& Young People

Document Version:

Peer reviewed version

Queen's University Belfast - Research Portal:

Link to publication record in Queen's University Belfast Research Portal

Publisher rights

(C) 2019 RCNI.

This work is made available online in accordance with the publisher's policies. Please refer to any applicable terms of use of the publisher.

\section{General rights}

Copyright for the publications made accessible via the Queen's University Belfast Research Portal is retained by the author(s) and / or other copyright owners and it is a condition of accessing these publications that users recognise and abide by the legal requirements associated with these rights.

Take down policy

The Research Portal is Queen's institutional repository that provides access to Queen's research output. Every effort has been made to ensure that content in the Research Portal does not infringe any person's rights, or applicable UK laws. If you discover content in the Research Portal that you believe breaches copyright or violates any law, please contact openaccess@qub.ac.uk. 
Title

Mental health and well-being of parents caring for a ventilator-dependent child

\section{Authors}

Julianne Lee BSc (Hons) RN and Fiona Lynn PhD MSc PGCHET BA (Hons)

Julianne Lee, Lead Nurse in Community Children's Services, Southern Health and Social Care Trust, Northern Ireland.

Fiona Lynn, Lecturer in Maternal and Child Health, Queen's University Belfast, Northern Ireland

\section{Corresponding author}

Dr Fiona Lynn, School of Nursing and Midwifery, Queen's University Belfast, Medical Biology Centre, 97 Lisburn Road, Belfast, BT9 7BL, UK. Tel: +44 (0) 2890975784 . Fax: +44 (0) 28 90972328. Email: f.lynn@qub.ac.uk 


\section{Abstract}

An integrative literature review was undertaken to determine the social and emotional effects on the mental health and well-being of parents of children requiring long-term ventilation at home. Six studies were included. Recurrent themes reported in the literature included lack of formal and informal support, financial adversity, limited access to respite care and feelings of social isolation. These themes were associated with depressive symptoms and were consistently reported to have a negative effect on parental mental health and well-being. Healthcare professionals have a part to play in improving parents' coping skills, resilience and resourcefulness to help reduce adverse social and emotional effects on their mental health and well-being.

\section{Keywords}

Carers, child health, long-term ventilation, parents, mental health, well-being 


\section{Introduction}

Advances in medicine and medical technologies have enabled infants and children to survive life-threatening conditions associated with preterm birth, congenital anomalies, infectious diseases, accidents and injuries (Spratling 2015). However, some of these children fail to breathe independently and require long-term ventilation (LTV) (Noyes 2006). Children who require LTV were defined by Jardine and Wallis (1998) as: 'any child who when medically stable, continues to require a mechanical aid for breathing, after an acknowledged failure to wean, or are slow to wean three months after the institution of ventilation'.

Identifying the number of children requiring LTV is challenging: there is no central UK registry and there is a lack of consensus over a universal definition. There are also a range of specialist support services and healthcare professionals providing care. However, numbers of cases are increasing (Whiting 2009, Wallis et al 2011).

The number of children on LTV in the UK rose from 141 in 1998 to 933 in 2008 (Wallis et al 2011). No more up to date surveys on the number of children on LTV are available. This increase is reflected across all developed countries (Cancelinha et al 2015) and attributed to many factors, including technological advances, development of portable medical devices and improved outcomes following critical illness (Margolan et al 2004).

In the UK, the National Service Framework (NSF) for Children and Young People and Maternity Services (Department of Health (DH) 2004) stated that home was the best place to care for children with long-term health needs. This was further reinforced by the National Framework for Children and Young People's Continuing Care (DH 2010) and the current strategy (NHS England 2014). Parents, however, are not offered a choice and it is assumed, by parents, that medically stable children requiring LTV will be cared for at home (Lindahal and Lindbald 2011). 
This is despite the fact that these children have complex needs, with parents required to assume multiple roles and 24-hour responsibility (Lewis and Noyes 2007, Graham 2013).

A positive sense of well-being enables people to function effectively and meet the demands of everyday life. Those who experience good mental health can recover from significant life events (Mental Health Foundation 2015). The complex care of a child requiring LTV at home can have a negative effect on parents' mental health and wellbeing (Carnevale et al 2006, Kuster and Badr 2006). Although caring for a child requiring any form of technology dependence can cause parental stress, parenting a child with device-based respiratory support is exceptionally stressful, because any change can pose an immediate risk to life (Montagnino and Mauricio, 2004).

\section{Aim}

The aim of this integrative literature review was to determine the social and emotional effects on the mental health and well-being of parents of children on LTV who are being cared for at home.

\section{Methods}

Whittemore and Knafl's (2005) framework for conducting integrative reviews was followed. After identification of the literature review question, a systematic search strategy was developed to maximize the relevance of literature retrieved. The search terms focused on children, artificial respiration, non-invasive ventilation, parents, carers and home care. Search limits included English language publications and research published since 2005.

The time frame was chosen because the successful use of LTV for children at home has improved substantially in the past ten years. It also coincided with the Barnardo's publication 
From Hospital to Home (Noyes and Lewis 2005), which highlighted the potential effects of stress, anxiety, depression, exhaustion and sleep deprivation on parents' mental health. No limit was placed on type of study design.

Searches were conducted in May 2016 using MEDLINE, Embase and the Cumulative Index to Nursing and Allied Health Literature database CINAHL Plus. Titles and abstracts were screened for relevance and full texts of papers assessed for eligibility. Reference lists of relevant studies were also screened to identify any additional records. Studies were included if they reported the effect of caring for a child requiring LTV on a parent/carer's mental health and well-being. Studies were excluded if they researched groups of parents whose children were dependent on other types of technology, such as tracheostomy tubes, enteral feeding devices, urinary catheters and oxygen, and not exclusively mechanical ventilation.

Characteristics of included studies were extracted and narrative synthesis of findings was undertaken, as recommended by Whittemore and Knafl (2005), with emerging themes reported. A quality assessment was conducted using the relevant Critical Appraisal Skills Programme (2017) tools, with the strengths and limitations of each study identified.

\section{Results}

From the database searches, 71 records were identified, 11 of which were duplicates. Of the titles and abstracts screened, 47 were not relevant to the review question. A further seven were excluded after review of the full text as they did not meet the inclusion criteria.

Six studies were retained and are included in this integrative literature review. Three of these (Carnevale et al 2006, Mah et al 2008, Wang and Barnard 2008) adopted a qualitative phenomenological approach using face-to-face interviews, focus groups and/or field observations. Three others (Kuster and Badr 2006, Meltzer et al 2010, Hefner and Tsai 2013) 
took a quantitative observational approach with cross-sectional descriptive designs using questionnaire and survey-based methods. Themes identified as having an adverse emotional impact on parents and carers were:

- A lack of formal and informal support.

- Financial adversity.

- Limited access to respite care.

- Feelings of social isolation.

Table 1 summarises the characteristics of the studies. 
Table 1

Characteristics of Included Studies

\begin{tabular}{|c|c|c|c|c|c|}
\hline $\begin{array}{l}\text { Author } \\
\text { (year) \& } \\
\text { Location }\end{array}$ & Study Design & Sample & $\begin{array}{l}\text { Focus of the } \\
\text { study }\end{array}$ & Findings & Strengths \& Limitations \\
\hline \multicolumn{6}{|c|}{ QUALITATIVE } \\
\hline $\begin{array}{l}\text { Carnevale } \\
\text { et al (2006) } \\
\text { Quebec } \\
\text { Canada }\end{array}$ & $\begin{array}{l}\text { Interpretative } \\
\text { framework } \\
\text { Semi structured } \\
\text { interviews } \\
\text { Family interactions } \\
\text { recorded } \\
\text { Fieldwork } \\
\text { observations during } \\
\text { times that families } \\
\text { described as } \\
\text { significant } \\
\text { Thematic \& } \\
\text { interpretative data } \\
\text { analysis. }\end{array}$ & $\begin{array}{l}\text { Participants = } \\
38 \text { from } 11 \\
\text { families } \\
\text { Recruitment } \\
\text { via home } \\
\text { ventilation } \\
\text { programme. }\end{array}$ & $\begin{array}{l}\text { The moral } \\
\text { dimension of } \\
\text { the family } \\
\text { experience } \\
\text { when a child } \\
\text { required long- } \\
\text { term } \\
\text { ventilation } \\
\text { (LTV). }\end{array}$ & $\begin{array}{l}\text { Families faced daily distress but } \\
\text { enrichment also. } \\
\text { They felt they had no choice in } \\
\text { life support decisions with } \\
\text { provision of assisted ventilation. } \\
\text { High levels of isolation. } \\
\text { Services were fragmented. } \\
\text { Complexity of child's needs } \\
\text { caused extraordinary physical and } \\
\text { financial strains. } \\
\text { Moral distress. }\end{array}$ & $\begin{array}{l}\text { Strengths } \\
\text { Empirical methodology directly examining } \\
\text { lived experiences } \\
\text { Credibility supported through interviewers } \\
\text { spending time with participants } \\
\text { Preliminary findings and analysis discussed } \\
\text { with experts. } \\
\text { Data collection and analysis reviewed by } 2 \\
\text { investigators. } \\
\text { Limitations } \\
\text { Did not cover the perspective of parents who } \\
\text { chose not to mechanically ventilate their child } \\
\text { and allowed them to die. } \\
\text { Findings relate to a restricted geographic area } \\
\text { Other areas may have different support } \\
\text { mechanisms which could result in dissimilar } \\
\text { experiences } \\
\text { Fieldwork observations only involved three } \\
\text { families. }\end{array}$ \\
\hline
\end{tabular}




\begin{tabular}{|c|c|c|c|c|c|}
\hline $\begin{array}{l}\text { Author } \\
\text { (year) \& } \\
\text { Location }\end{array}$ & Study Design & Sample & $\begin{array}{l}\text { Focus of the } \\
\text { study }\end{array}$ & Findings & Strengths \& Limitations \\
\hline $\begin{array}{l}\text { Mah et al } \\
\text { (2008) } \\
\text { Alberta } \\
\text { Western } \\
\text { Canada }\end{array}$ & $\begin{array}{l}\text { Phenomenological } \\
\text { Interviews in child's } \\
\text { home audio-recorded } \\
\text { and transcribed } \\
\text { verbatim } \\
\text { Interview guide used } \\
\text { and amended based } \\
\text { on an iterative style } \\
\text { to detect parent's } \\
\text { caregiving } \\
\text { experience. } \\
\text { Final interview } \\
\text { semi-structured. }\end{array}$ & $\begin{array}{l}19 \\
\text { participants } \\
\text { from } 15 \\
\text { families (15 } \\
\text { mothers and } \\
\text { four fathers) } \\
\\
\text { Recruited } \\
\text { from parents } \\
\text { of children } \\
\text { (aged 2-18 } \\
\text { years) who } \\
\text { attended } \\
\text { clinics in two } \\
\text { metropolitan } \\
\text { cities. }\end{array}$ & $\begin{array}{l}\text { The experience } \\
\text { of parents } \\
\text { caring for a } \\
\text { child with } \\
\text { neuromuscular } \\
\text { disease } \\
\text { requiring LTV } \\
\text { at home with } \\
\text { the aim of } \\
\text { assisting } \\
\text { Health Care } \\
\text { Professionals } \\
\text { to approach } \\
\text { families with } \\
\text { greater } \\
\text { understanding. }\end{array}$ & $\begin{array}{l}\text { Once home ventilation } \\
\text { commenced there was an increase } \\
\text { in care giving responsibilities and } \\
\text { stress } \\
\text { Parents expressed guilt about lack } \\
\text { of sibling attention and pressure } \\
\text { on marital relations } \\
\text { Isolated and socially restricted } \\
\text { resulting in challenged friendships } \\
\text { Increased anxiety due to living } \\
\text { with uncertainty. They were their } \\
\text { child's 'lifeline' with gaps in } \\
\text { healthcare and inadequate support } \\
\text { increasing 'burden of caring' and } \\
\text { resulting in higher risk of stress } \\
\text { related illness and adverse } \\
\text { psychological outcomes. }\end{array}$ & $\begin{array}{l}\text { Strengths } \\
\text { Appropriate methodology and research design } \\
\text { Trained Research Assistant recruited families } \\
\text { Relationship between researcher \& } \\
\text { participants observed. } \\
\text { Interviews undertaken by researcher who was } \\
\text { not part of the healthcare team } \\
\text { Credibility accomplished via process of } \\
\text { verification. Investigators coded interviews } \\
\text { independently and met to review and reach } \\
\text { consensus increasing dependability. Detailed } \\
\text { records to facilitate clear audit trail } \\
\text { Preliminary findings presented in focus } \\
\text { groups to ensure valid description of data. } \\
\text { Limitations } \\
\text { Sample size small with only } 15 \text { of the } 25 \\
\text { eligible families participating. Although } \\
\text { overwhelming consensus on key themes } \\
\text { parents who declined may have reported } \\
\text { different experiences. }\end{array}$ \\
\hline
\end{tabular}




\begin{tabular}{|c|c|c|c|c|c|}
\hline $\begin{array}{l}\text { Author } \\
\text { (year) \& } \\
\text { Location } \\
\end{array}$ & Study Design & Sample & $\begin{array}{l}\text { Focus of the } \\
\text { study }\end{array}$ & Findings & Strengths \& Limitations \\
\hline $\begin{array}{l}\text { Wang and } \\
\text { Barnard } \\
(2008) \\
\text { Australia }\end{array}$ & $\begin{array}{l}\text { Phenomenographic } \\
\text { Face to face } \\
\text { audiotaped } \\
\text { interviews \& } \\
\text { transcribed verbatim } \\
\text { Open ended } \\
\text { questions. }\end{array}$ & $\begin{array}{l}17 \\
\text { participants } \\
11 \text { mothers, } \\
\text { four fathers, } \\
\text { one sibling } \\
\text { (aged 15) and } \\
\text { one carer. }\end{array}$ & $\begin{array}{l}\text { The } \\
\text { experiences of } \\
\text { primary } \\
\text { caregivers who } \\
\text { support } \\
\text { ventilator } \\
\text { dependent } \\
\text { children at } \\
\text { home. }\end{array}$ & $\begin{array}{l}\text { Presence of healthcare } \\
\text { professionals in their home was } \\
\text { stressful. } \\
\text { Parents experienced social } \\
\text { isolation and limited opportunity } \\
\text { for social experiences } \\
\text { Insufficient social support } \\
\text { Feelings of loneliness, frustration, } \\
\text { reduced freedom and choice. } \\
\text { Role ambiguity due to multiple } \\
\text { roles } \\
\text { Caregiving associated with a } \\
\text { positive attitude to life, increased } \\
\text { empathy and greater personal } \\
\text { strength \& resilience. }\end{array}$ & $\begin{array}{l}\text { Strengths } \\
\text { Strict adherence to phenomenographic } \\
\text { methods } \\
\text { Data and research outcomes examined by two } \\
\text { other experienced researchers. } \\
\text { Limitations } \\
\text { Recruitment strategy not described. } \\
\text { No detail provided regarding potential sample } \\
\text { size. }\end{array}$ \\
\hline \multicolumn{6}{|c|}{ QUANTITATIVE } \\
\hline $\begin{array}{l}\text { Kuster and } \\
\text { Badr } \\
(\mathbf{2 0 0 6 )} \\
\text { USA }\end{array}$ & $\begin{array}{l}\text { Cross-sectional } \\
\text { Data collected over } \\
\text { six months using } \\
\text { questionnaires \& } \\
\text { Interviews } \\
\text { Data collected using: }\end{array}$ & $\begin{array}{l}38 \\
\text { participants. } \\
34 \text { mothers, } \\
\text { two adoptive } \\
\text { mothers, one } \\
\text { grandmother, }\end{array}$ & $\begin{array}{l}\text { Explore the } \\
\text { mental health } \\
\text { of mothers } \\
\text { caring for } \\
\text { children } \\
\text { requiring LTV } \\
\text { at home } \\
\text { identifying the }\end{array}$ & $\begin{array}{l}\text { Support for potential negative } \\
\text { effects on mental health of } \\
\text { mothers caring for a child } \\
\text { requiring LTV } \\
45 \%(n=17) \text { scored } 16 \text { or greater } \\
\text { on the CES-D indicating } \\
\text { depressive moods. Significant }\end{array}$ & $\begin{array}{l}\text { Strengths } \\
\text { Design appropriate, however, researchers } \\
\text { recognize value in a longitudinal study } \\
\text { Clear recruitment strategy and detailed data } \\
\text { analysis provided. } \\
\text { Limitations }\end{array}$ \\
\hline
\end{tabular}




\begin{tabular}{|c|c|c|c|c|c|}
\hline $\begin{array}{l}\text { Author } \\
\text { (year) \& } \\
\text { Location } \\
\end{array}$ & Study Design & Sample & $\begin{array}{l}\text { Focus of the } \\
\text { study }\end{array}$ & Findings & Strengths \& Limitations \\
\hline & $\begin{array}{l}\text { Impact on Family } \\
\text { Scale, Social } \\
\text { Support Index, } \\
\text { Coping Health } \\
\text { Inventory, } \\
\text { Epidemiological } \\
\text { Studies Depression } \\
\text { Scale (CES-D). }\end{array}$ & $\begin{array}{l}\text { one foster } \\
\text { mother. } \\
\text { Recruitment } \\
\text { from a large } \\
\text { Children's } \\
\text { Hospital. }\end{array}$ & $\begin{array}{l}\text { relationship } \\
\text { between the } \\
\text { functional } \\
\text { status of the } \\
\text { child on } \\
\text { coping \& } \\
\text { maternal } \\
\text { depression. }\end{array}$ & $\begin{array}{l}\text { relationships between independent } \\
\text { variables and depression } \\
\begin{array}{l}\text { Effect of illness and frequency of } \\
\text { hospital admissions resulted in } \\
\text { greater depressive symptoms }\end{array} \\
\begin{array}{l}\text { Higher levels of social support } \\
\text { related to less depressive } \\
\text { symptoms }\end{array} \\
\text { Functional status of children not } \\
\text { related to depression. }\end{array}$ & $\begin{array}{l}\text { Small sample size } n=38 \text { : originally } 72 \\
\text { mothers expressed interest in participating but } \\
\text { did not follow through } \\
\text { Group of children was heterogeneous in } \\
\text { relation to condition and prognosis } \\
\text { Self-esteem, marital and life satisfaction not } \\
\text { measured despite fact they could significantly } \\
\text { affect maternal mental health. }\end{array}$ \\
\hline $\begin{array}{l}\text { Meltzer et } \\
\text { al (2010) } \\
\text { USA }\end{array}$ & $\begin{array}{l}\text { Cross-sectional } \\
\text { descriptive } \\
\text { Single telephone } \\
\text { interview to } \\
\text { complete all } \\
\text { measures with } \\
\text { exception of } 24 \text { hour } \\
\text { sleep patterns, which } \\
\text { took place over four } \\
\text { telephone interviews } \\
\text { in two-week period } \\
\text { Data collected using: } \\
\text { 24-hour Sleep } \\
\text { Pattern Inventory, }\end{array}$ & $\begin{array}{l}36 \\
\text { participants } \\
\text { Primary } \\
\text { caregivers } \\
(27 \text { mothers, } \\
\text { seven fathers, } \\
\text { one foster } \\
\text { mother and } \\
\text { one } \\
\text { grandmother }) \\
\text { Recruitment } \\
\text { through home } \\
\text { care } \\
\text { programme. }\end{array}$ & $\begin{array}{l}\text { Relationship } \\
\text { between home } \\
\text { nursing } \\
\text { support and } \\
\text { sleep, mood } \\
\text { and daytime } \\
\text { functioning of } \\
\text { parents/ } \\
\text { caregivers of } \\
\text { ventilator- } \\
\text { assisted } \\
\text { children. }\end{array}$ & $\begin{array}{l}\text { No significant differences in sleep } \\
\text { patterns for caregivers with or } \\
\text { without daytime support } \\
\text { Significant differences found with } \\
\text { night-time support. Caregivers } \\
\text { with less than } 16 \text { hours' night } \\
\text { cover had higher levels of clinical } \\
\text { depressive symptoms with shorter } \\
\text { sleep and more negative mood } \\
\text { Caregiver's ability to make } \\
\text { decisions, work performance and } \\
\text { stress all affected by lack of sleep. }\end{array}$ & $\begin{array}{l}\begin{array}{l}\text { Strengths } \\
\text { Clear rationale for study } \\
\text { Recognised measures used to collect data. } \\
\text { Limitations } \\
\text { All measures subjective and completed by a } \\
\text { single reporter }\end{array} \\
\text { Richness of data limited due to cross- } \\
\text { sectional design } \\
\text { Small sample resulted in insufficient capacity } \\
\text { to detect differences in some variables. Only a } \\
\text { small number of fathers included. }(\mathrm{n}=7)\end{array}$ \\
\hline
\end{tabular}




\begin{tabular}{|c|c|c|c|c|c|}
\hline $\begin{array}{l}\text { Author } \\
\text { (year) \& } \\
\text { Location }\end{array}$ & Study Design & Sample & $\begin{array}{l}\text { Focus of the } \\
\text { study }\end{array}$ & Findings & Strengths \& Limitations \\
\hline & $\begin{array}{l}\text { CES-D, Iowa } \\
\text { Fatigue Scale, } \\
\text { Stanford Sleepiness } \\
\text { Scale. }\end{array}$ & & & $\begin{array}{l}\text { Nursing support particularly at } \\
\text { night is important for caregiver } \\
\text { health and well-being. }\end{array}$ & $\begin{array}{l}\text { Convenience sample compromised } \\
\text { generalizability. }\end{array}$ \\
\hline $\begin{array}{l}\text { Hefner and } \\
\text { Tsai (2013) } \\
\text { USA }\end{array}$ & $\begin{array}{l}\text { Survey completed } \\
\text { during clinic visit- } \\
\text { data collected over a } \\
\text { nine-month period } \\
\text { Monetary incentive. }\end{array}$ & $\begin{array}{l}\begin{array}{l}\text { Convenience } \\
\text { sample } \\
(\mathrm{n}=122 \\
\text { parents) }\end{array} \\
\text { Recruitment } \\
\text { through } \\
\text { Children's } \\
\text { Home } \\
\text { Ventilator } \\
\text { Clinic. }\end{array}$ & $\begin{array}{l}\text { The themes of } \\
\text { unmet need } \\
\text { and care co- } \\
\text { ordination and } \\
\text { develop a } \\
\text { comprehensive } \\
\text { socio- } \\
\text { demographic } \\
\text { profile of } \\
\text { ventilator } \\
\text { dependent } \\
\text { children. }\end{array}$ & $\begin{array}{l}\text { Depressive symptoms associated } \\
\text { with financial struggles and unmet } \\
\text { need in coordination of care } \\
16.4 \%(\mathrm{n}=20) \text { screened positive } \\
\text { for probable depressive disorder } \\
40 \%(\mathrm{n}=49) \text { reported feeling } \\
\text { depressed and had little interest } \\
\text { and pleasure in life on many days } \\
\text { Caregiver mental health may be } \\
\text { an important point of intervention } \\
\text { for service provision. }\end{array}$ & $\begin{array}{l}\text { Strengths } \\
\text { Large scale survey ( } 84 \% \text { of clinic population) } \\
\text { facilitates investigation of statistical } \\
\text { associations described in previous small } \\
\text { sample studies } \\
\text { Research Design and methods clearly stated } \\
\text { with robust recruitment strategy described } \\
\text { Limitations } \\
\text { Lack of precision in analysis due to sample } \\
\text { size - not possible to conduct multivariate } \\
\text { analysis and bivariate tests of association } \\
\text { subject to large confidence intervals } \\
\text { Study population may not be representative of } \\
\text { other locations and variability of resources } \\
\text { and regional practices affect generalizability. }\end{array}$ \\
\hline
\end{tabular}


Lack of formal and informal support

The level of formal and informal support and its effect on mental health and well-being was reported in six studies. Quality of life was affected by insufficient nursing support, sleep deprivation and caregiver depression (Carnevale et al 2006, Kuster and Badr 2006, Mah et al 2008, Wang and Barnard 2008, Meltzer et al 2010, Hefner and Tsai 2013).

Using a cross-sectional descriptive design, Meltzer et al (2010) explored the relationship between nursing support at home, sleep, mood and daytime functioning of 36 primary carers over a two-week period.

Although a small sample was recruited, which resulted in insufficient capacity to expose differences in some variables, reduced nursing support at night was associated with less sleep and a more negative mood. Those receiving fewer than 16 nursing hours at night scored above the clinical cut off for depressive symptoms, measured using the Center for Epidemiologic Studies Depression Scale (CES-D) (Radloff 1977). In contrast, no significant differences in sleep patterns were found for those without consistent daytime support.

The CES-D has consistently shown sufficient internal reliability in studies of carers (Kub 2017). It was also used by Kuster and Badr (2006) who reported $45 \%(n=17)$ of mothers of children requiring $L T V$ scored $\geq 16$, indicating they were experiencing depressive symptoms. Mothers who reported good social support had lower scores on the depression measure $(r=-0.4$; $\mathrm{p}<0.05)$. Kuster and Badr (2006) concluded that the level of support was a significant predictor for depression; a finding echoed throughout the included studies (Carnevale et al 2006, Mah et al 2008, Wang and Barnard 2008, Meltzer et al 2010, Hefner and Tsai 2013). Although Hefner and Tsai (2013) applied a different measure to assess caregiver's mental health, their findings were similar, with $40 \% \quad(n=49)$ of respondents reporting frequent depressive symptoms. 
The provision of home nursing care was unanimously supported, but the resulting lack of privacy was reported as stressful (Wang and Barnard 2008), creating tension in marital relationships (Carnevale et al 2006) and limiting opportunity for intimacy (Mah et al 2008).

Kuster and Badr (2006) acknowledged that although their study found a high incidence of depressive symptoms, only two variables were significant indicators: a high number of hospital admissions $(r=0.40 ; p<0.05)$ and level of social support $(r=-0.40 ; p<0.05)$.

\section{Financial adversity}

All included studies reported the effect of financial adversity on parental mental health and well-being. Family finances and caregiver depression were independently associated with an unmet need for care coordination and support (Hefner and Tsai 2013). Financial challenges and resultant stress and depression were also reported by Wang and Barnard (2008) and Mah et al (2008). Carnevale et al (2006) described those families with limited financial reserves as particularly vulnerable and disadvantaged.

Financial considerations about provision of care were also described by Meltzer et al (2010), who reported that families chose daytime support to facilitate work, which was essential from a financial perspective. However, this resulted in parents becoming night-time carers by default, which had a negative effect on their mental health and well-being.

Limited access to respite care and feelings of social isolation

Respite was fundamental to alleviate the stress and isolation associated with caring commitments (Carnevale et al 2006, Kuster and Badr 2006, Mah et al 2008, Wang and Barnard 2008, Meltzer et al 2010, Hefner and Tsai 2013). However, most parents had difficulty accessing respite and found neither extended family nor the healthcare system could provide 
reliable respite care (Carnevale et al 2006, Mah et al 2008, Meltzer et al 2010, Hefner and Tsai 2013). This inevitably resulted in social isolation, a common recurring theme cited in four of the six research papers (Carnevale et al 2006, Mah et al 2008, Wang and Barnard 2008, Meltzer et al 2010). The sense of social isolation experienced by parents was described as profound; on occasion, the intense loneliness expressed was upsetting for researchers to witness (Carnevale et al 2006).

Kuster and Badr (2006) and Mah et al (2008) found parents, especially mothers, imposed social restrictions on themselves and their families, as it took too much energy to organise simple activities. The perception of isolation was further heightened when friendships were challenged by genuine inability to commit to social events.

Self-imposed isolation also provided a way of avoiding negative reactions from the public. This analogy was supported by Wang and Barnard (2008), who reported that the constant need for care led to confinement and decreased opportunities for social activities with social discrimination augmenting feelings of isolation and loneliness.

One family interviewed by Carnevale et al (2006) preferred to enclose themselves at home to avoid hurtful social encounters. Carnevale et al (2006) also reported that parents experienced a lack of kinship. This could suggest an intrinsic gender difference in how isolation was managed or the fact that most fathers worked outside the home, which helped counteract their sense of isolation.

Using the Impact on Family Scale and Social Support Index Scale, Kuster and Badr (2006) measured levels of social support and disruption to normal social interactions outside the family home. The results indicated that social support was a significant predictor of mother's depression, and assistance from families and healthcare services was a powerful resource. This can buffer the effect of caregiving and minimise mental stress. Wang and Barnard (2008) 
recognised that more respite opportunities and increased practical support would considerably reduce the experience of isolation and the feeling of 'being different'.

Support from both healthcare providers and extended family appeared to mediate parental stress by allowing them to have a break from caring (Kuster and Badr 2006, Mah et al 2008, Wang and Barnard 2008).

Overall, the studies reported common and recurrent themes experienced by parents, because of the amount of care their child required. A lack of formal and informal support, financial adversity, limited access to respite care and feelings of social isolation were significantly associated with depressive symptoms and low social and emotional well-being.

In synthesising these themes, an overarching element emerged relating to change in the meaning of parenting and the parenting experience. This change came from parents taking on multiple roles, as caregiver, advocate, educator, case manager and expert in their child's condition (Carnevale et al 2006, Mah et al 2008, Wang and Barnard 2008). The overwhelming responsibility and resourcefulness needed in parenting a child on LTV increased the levels of stress experienced on an ongoing basis.

In exploring the social and emotional effect on parents of caring for a child on LTV, the integrative review process also assessed any dissenting voices to the main themes. When reviewing the studies, the primary deviant case emerged was that despite the hardship faced, parents experienced a deep sense of personal enrichment because of their caring (Carnevale et al 2006, Mah et al 2008, Wang and Barnard 2008). Wang and Barnard (2008) found that the parents they talked to had a positive attitude to life, increased empathy and greater personal strength and resilience.

\section{Discussion}


The findings of this review were derived from both qualitative and quantitative studies and offer a better understanding of what it is like for parents of children who require LTV and the subsequent distress that can be experienced.

They also help identify where effective support is needed to improve parental social and emotional health and wellbeing. However, further research is needed to gain a greater appreciation of the lived experiences of caring for a child requiring LTV at home and identify mechanisms for change. Interventions could be developed and examined to deliver effective strategies to support parents practically and emotionally, as recommended by Kuster and Badr (2006).

Further research and approaches are required to promote collaboration, enhance coordination of care (Mah et al 2008) and provide a more detailed account of potential adverse effects on mental health.

While the research design of the included studies was appropriate, the value of a longitudinal study is recognised. This would allow for experiences to be examined at different stages of a child's illness trajectory. With the level of formal and informal support, financial circumstances, access to respite care and social isolation changing over time, outcomes relating to the social and emotional health and well-being of parents could be affected (Kuster and Badr 2006).

Longitudinal cohort research can capture complexities, track progress, explore experiences and outcomes and enable new ways of thinking (Morrow and Crivello 2015).

One study solely recruited mothers, however, the majority of participants across all the studies were women - and primarily mothers. Fathers of children on LTV were underrepresented. This may reflect the fact that primary caregivers are predominantly mothers 
(Cooke et al 2010). However, future research should consider the social and emotional health and well-being of both parents, as recommended by Meltzer et al (2010).

Although this review focused on parents of children requiring LTV, the findings could be considered in the wider context of caring for children with complex healthcare needs at home. Mothers are generally the primary caregivers for technology-dependent children, and research indicates high levels of depressive symptoms affecting carer and child (Toly et al 2014).

With increasing numbers of technology-dependent children being cared for at home (Whiting 2014) and with evidence in this review that caring for a child requiring LTV affects the social and emotional health and well-being of parents, policy makers and care providers must take this into consideration.

The expansion of services and interventions that can reduce the adversities faced by these parents is vital (Carnevale et al 2006). Cockett (2012), as part of a review relating to technology dependent children, reported the practical implications for parents of caring for a child at home and the need for services to support parents.

In Northern Ireland, the Department of Health, Social Services and Public Safety (2011) acknowledged that existing services are often ill equipped to support the carers of children with complex physical healthcare needs. This recognition has resulted in the commissioning of a research development project focusing on this group of children.

The aim is to obtain a better understanding of their needs to assist in identifying promising service responses (Public Health Agency 2011). This, in turn, may make it easier for parents to gain as much enrichment as possible from their challenging lives. Meltzer et al (2010) emphasised the need to explore ways to safeguard and improve parental mental health and well-being. 
An appropriate level of nursing support and innovative and reliable respite care are recommended. Helping carers to have a social life would inevitably reduce feelings of isolation and confinement, which could reduce depressive symptoms.

Interventions to include screening for depression, educating parents about appropriate expectations, enhancing their coping skills and assisting them to access a social network to help mediate carer stress are recommended (Carnevale et al 2006).

Wang and Barnard (2008) affirmed that healthcare professionals and policymakers must respond to the experiences of the growing number of carers. Enhancing the provision of support services, psychological counselling, information and practical help, with improved multi-professional and multi-agency collaboration should be considered. Meltzer et al (2010) further emphasised disjointed partnership between healthcare professionals and parents and the need to increase home nursing support.

Respite care for parents of children who require LTV is a central component of any care package (Noyes 2006) and its necessity is outlined in the NSF for Children, Young People and Maternity Services: LTV (DH 2005). However, availability is limited and there is considerable variation (Cooke et al 2010, Whiting 2014).

Adequate financial provision and approaches for maintaining quality of life are essential criteria in planning, providing and evaluating care needs (Kuster and Badr 2008).

Caregiver mental health and financial difficulties are important points of intervention, addressed by strengthening collaboration across public agencies and directing human and financial resources towards appropriate solutions, such as care coordination programmes that are tailored to the individual and the family (Hefner and Tsai, 2013).

Parenting a child who is technology dependent changes the meaning of parenting, with the practicality of care provision having an overwhelming emotional effect. Professionals should 
recognise their role in providing emotional support and developing parents' coping skills (Kirk et al 2005). Churchill et al (2010) found that, regardless of the child's diagnosis, enhanced coping abilities were linked with fewer depressive symptoms and facilitated parent empowerment, self-efficacy, resilience and resourcefulness. This may then mitigate against depressive symptoms.

Although similar themes were identified across all studies in this review, the small number of papers and lack of generalisability of the findings because of small sample sizes, influence the robustness of the synthesised evidence. Despite this, the negative effect on the social and emotional health and well-being of parents caring for a child at home requiring LTV is highlighted, along with the joy that the caring role can bring.

Research in the area is lacking, perhaps due to the new concept of home care for children with LTV being relatively new. Research has mainly focused on the discharge process (Lewis and Noyes 2007) and resource and service costs (Noyes et al 2006, Wallis et al 2011), rather than addressing long-term issues.

\section{Conclusion}

As Western society invests in advanced lifesaving technology it could be viewed as a moral obligation that individualised support is offered to parents of children requiring LTV with an emphasis on the importance of parental health and well-being.

Parenting a child who is dependent on technology changes the meaning of parenting. Healthcare professionals should appreciate the emotional dimension, offering support and exploring methods to increase parental coping skills, resilience and resourcefulness through the provision of targeted interventions to reduce psychological distress and depression. 


\section{References}

Cancelinha C, Madurera M, Macao P, Pleno P, Silva T, Estevao M, Felix M (2015) Long Term Ventilation in Children. 10 Years Later. Portuguese Journal of Pulmonology. 21, 1, 16-21.

Carnevale F, Alexander E, Davies M, Rennick J, Trioni R (2006) Daily Living with Distress and Enrichment: The Moral Experience of Families with Ventilator Assisted Children at Home. Pediatrics. 117, 1, 48-60.

Churchill S, Villareale, N, Monaghan, T, Sharp, V, Kieckhefer, G (2010) Parents of children with special healthcare needs who have better coping skills have fewer depressive symptoms. Maternal and Child Health Journal. 14, 1, 47-57.

Cockett A (2012) Technology dependence and children: a review of the evidence. Nursing Children and Young People. 24, 1, 32-35.

Cooke A., Harris S, Kenny H, Ruthven T, Widdas D (2010) A Toolkit to Support Ventilated Children and Young People in Children's Hospices. Department of Health: London.

Critical Appraisal Skills Programme (2014) CASP Qualitative Checklist. http://media.wix.com/ugd/dded87

Department of Health (2004) National Service Framework - Children, Young People and Maternity Services. London: DOH.

Department of Health (2005) Department of Education and Skills National Service framework for Children Young People and families Exemplar; Long Term Ventilation. London. DOH. Department of Health (2010) National Frameworkfor Children and Young People's Continuing Care. London: DOH.

Department of Health Social Services and Public Safety (2011) Transforming Your Care; A Review of Health and Social Care in Northern Ireland. Belfast: DHSSPSNI. 
Graham R (2013) Long-Term Ventilation: Charting a Pathway Home. Archives of Disease in Childhood. 98, 9, 653.

Hefner J, Tsai W (2013) Ventilator-Dependent Children and the Health Services System Unmet Needs and Coordination of Care. Annals of the American Thoracic Society. 10, 5, 482-489.

Jardine E, Wallis C (1998) Core Guidelines for Discharge Home of the Child on Long Term Ventilation in the United Kingdom. Thorax. 53, 9, 762-767.

Kirk S, Glendinning C, Callery, P (2005) Parent or Nurse? The experience of being a parent of a technology-dependent child. Journal of Advanced Nursing. 51, 5, 456-464.

Kub J, Bellin MH, Butz A et al (2017) The chronicity of depressive symptoms in mothers of children with asthma. Western Journal of Nursing Research. doi.org/10.1177/0193945917705858

Kuster P, Badr L (2006) Mental Health of Mothers Caring for Ventilator - Assisted Children at Home. Issues in Mental Health Nursing. 27, 8, 817-835.

Lewis M, Noyes J (2007) Discharge Management for Children with Complex Needs. Paediatric Nursing. 19, 4, 26-30.

Lindahl B, Lindblad B (2011) Family members' experiences of everyday life when a child is dependent on a ventilator. A Metasynthesis Study. Journal of Family Nursing. 17, 2, 241-269. Mah J, Thannhauser J, McNeill D, Dewey D (2008) Being the lifeline: the parent experience of caring for a child with neuromuscular disease on home mechanical ventilation. Neuromuscular Disorders. 18, 12, 938-988.

Margolan H, Fraser J, Lennon S (2004) Parental experience of services when their child requires long-term ventilation. Implications for commissioning and providing services. Child Care, Health and Development. 30, 3, 257-264. 
Meltzer LJ, Boroughs DS, Downes JJ (2010) The Relationship Between Home Nursing Coverage, Sleep and Daytime Functioning in Parents of Ventilator-Assisted Children. Journal of Pediatric Nursing. 25, 4, 250-257.

Mental Health Foundation (2015) www.mentalhealth.org.uk (accessed 31 May 2016)

Montagnino B, Mauricio R (2004) The Child with a tracheostomy and gastrostomy: Parental stress and coping in the home- A pilot Study. Paediatric Nursing. 30, 5, 373-380.

Morrow V, Crivello G (2015) What is the value of qualitative longitudinal research with children and young people for international development? International Journal of Social Research Methodology. 18, 3, 267-280.

NHS England (2014) Five Year Forward View. London: National Health Service England. Noyes J (2006) Health and quality of life of ventilator dependent children. Journal of Advanced Nursing. 56, 4, 392-403.

Noyes J, Lewis M (2005) From Hospital to Home: Guidance for Discharge Management and Community Support for Children Requiring long Term Ventilation. Essex: Barnardos. Noyes J, Godfrey C, Beecham J (2006) Resource use and service costs for ventilator-dependent children and young people in the UK. Health \& Social Care in the Community. 14, 6, 508-522. Public Health Agency (2011) Regional Interagency Implementation Group Children with Complex Needs. Belfast: DHSSPSNI.

Radloff LS (1977) The CES-D Scale: a self-report depression scale for research in the general population. Applied Psychological Measurement. 1, 385-401.

Spratling R (2015) Defining technology dependence in children and adolescents. Western Journal of Nursing research. 37, 5, 634-651. 
Toly V, Musil C, Zauszniewski J (2014) Resourcefulness training intervention: A promising approach to improve mental health of mothers with technology-dependent children. Applied Nursing Research. 27, 1, 87-90.

Wallis C, Paton J, Beaton S, Jardine E (2011) Children on long term ventilator support: 10 years of progress. Archives of Disease in Childhood. 96, 11, 998-1002.

Wang KW, Barnard A (2008) Caregivers' Experiences at home with a Ventilator- Dependent Child. Qualitative Health Research. 18, 40, 501- 507.

Whiting M (2009) Is this my Life? Meaning and sense making as key determinants of parents when caring for children with disabilities, life threatening/life limiting illnesses or technology dependence. Unpublished PhD Thesis, London: Southbank University.

Whiting M (2014) Support requirements for parents caring for a child with disability and complex health needs. Nursing Children and Young People. 26, 4, 24-27.

Whittemore R, Knafl K (2005) The integrative review: updated methodology. Journal of Advanced Nursing. 52, 5, 546-553. 